\title{
Origin Recognition Complex Subunit 2
}

National Cancer Institute

\section{Source}

National Cancer Institute. Origin Recognition Complex Subunit 2. NCI Thesaurus. Code C34014.

Origin recognition complex subunit 2 ( $577 \mathrm{aa}, \sim 66 \mathrm{kDa}$ ) is encoded by the human ORC2 gene. This protein is involved in DNA replication initiation. 